\title{
Climate change and social vicissitudes in China over the past two millennia
}

\author{
Jun Yin ${ }^{\mathrm{a}, \mathrm{b}}$, Yun Su ${ }^{\mathrm{b}, *}$, Xiuqi Fang ${ }^{\mathrm{b}}$ \\ ${ }^{a}$ Key Laboratory of Land Surface Pattern and Simulation, Institute of Geographical Sciences and Natural Resources Research, Chinese Academy of Sciences, \\ Beijing, 100101, PR China \\ b School of Geography, Beijing Normal University, No. 19 Xin Jie Kou Wai Street, Haidian District, Beijing, 100875, PR China
}

\section{A R T I C L E I N F O}

\section{Article history:}

Received 11 March 2016

Available online 11 August 2016

\section{Keywords:}

Climate change

Semantic Differential technique

Quantitative series

Social rise and fall

Past two millennia

China

\begin{abstract}
A B S T R A C T
The relation between climate change and historical rhythms has long been discussed. However, this type of study still faces the lack of high-resolution data concerning long-term socio-economic processes. In this study, we collected 1586 items of direct and proffered evidence from 29 Chinese history books. We used semantic analysis to reconstruct a quantitative series of the social vicissitudes of the past $2000 \mathrm{yr}$ with a 10-yr resolution to express the phase transition of the social vicissitudes of the dynasties in China. Our reconstruction demonstrates that social vicissitudes have clear cyclical features on multiple time scales. Analysis of the association of social rise and fall with climate change indicates that temperature displayed more significant effects on social vicissitudes in the long term, while precipitation displayed more significant effects on the social vicissitudes in the short term. There are great overlaps between social and climatic variables around the predominant or periodic bands. Social rise mostly occurred in the centennial-scale warm periods, whereas social decline mostly occurred in the centennial-scale cold periods. Under warm-wet conditions, social rise occurred over $57 \%$ of the time; under cold-dry conditions, the social decline occurred over $66 \%$ of the time.
\end{abstract}

๑ 2016 University of Washington. Published by Elsevier Inc. All rights reserved.

\section{Introduction}

Knowledge of the impact of climate change on social vicissitudes and the associated human responses can provide historical references for dealing with current and future global climate change (PAGES, 2009). As an external condition of social development, climate change impact is the result of interactions between a variety of factors in both natural and social systems and at multiple temporal and spatial scales (Fang et al., 2015). Climate change has long been suggested to be an important factor in facilitating sustainable human development (Issar and Zohar, 2007; Ge et al., 2013a). During recent decades, many research studies have been conducted worldwide regarding the impacts of historical climate change; for example, the impact of climate change on agricultural production, human population and migration, disease and human health, human settlements, human activities, social unrest, the rise and fall of ancient civilizations, and transmission of climate change impacts (Weiss and Bradley, 2001; Haug et al., 2003; Zhang et al.,

\footnotetext{
* Corresponding author.

E-mail addresses: yinjun@mail.bnu.edu.cn (J. Yin), suyun@bnu.edu.cn (Y. Su), xfang@bnu.edu.cn (X. Fang).
}

2007, 2011; 2015; Fan, 2010; Lee and Zhang, 2010; Büntgen et al., 2011; Amorosi et al., 2013; Hsiang et al., 2013; Welc and Marks, 2014; Chull et al., 2014; Su et al., 2014; Zheng et al., 2014; Wei et al., 2014, 2015; Yin et al., 2015; Fang et al., 2015; Xiao et al., 2015). The results include the drought-induced collapse of the Akkadian civilization in western Asia and the Mayan civilization (deMenocal, 2001; Haug et al., 2003) and the strong coincidence between climate change and major events in the history of central Europe over the past $2500 \mathrm{yr}$ (Büntgen et al., 2011).

Recent decades have witnessed intensive progress in documenting past climatic change around the world. In particular, there have been great improvements in high-resolution paleoclimatic reconstructions that span past millennia (IPCC, 2013). Many studies have concluded that the last two millennia exhibited several warmer and colder stages, notably, the "Medieval Warm Period" and the "Little Ice Age" (Crowley and Lowery, 2000; Mann et al., 2009). These paleoclimatic records make it possible to quantitatively study the long-term relation between climatic elements and historical change.

In contrast, high-resolution and continuous proxy series of societies that extend more than $1000 \mathrm{yr}$ into the past are limited. Because of this limitation, understanding of the mechanisms by 
which climate change impacts the social economy remains limited. A few studies have quantitatively revealed the long-term temporal coincidence and potential association between cold climatic phases and crises in agriculture, population, economy and society (Zhang et al., 2007, 2011, 2015; Tol and Wagner, 2010; Büntgen et al., 2011; Dybdahl, 2012; Zheng et al., 2014; Wei et al., 2014, 2015; Su et al., 2014; Yin et al., 2015; Fang et al., 2015).

However, these studies investigated the effects of climate change on such social processes as population, agriculture, and economy; research on the direct effects of climate change on social vicissitudes is still lacking. This knowledge gap has triggered controversies and arguments regarding the historical impact of climate change, for example, whether a monsoon could have "blown down" the Tang Dynasty (Yancheva et al., 2007a, 2007b; Zhang and Lu, 2007; Zhang et al., 2008; Zhang, 2008; Zhang et al., 2010a, 2010b; Cheng et al., 2010). Thus, development of long-term quantified social vicissitudes series, which are able to match the climate change series in both length and time resolution, is urgently needed to better understand the impacts of historical climate change on society. However, these analyses are restricted by the availability of historical data.

China has long-term, continuous, and rich historical documents that international scholars recognize as a unique resource for the reconstruction of historical climate change. Modern historians in China also have constructed an authoritative description of Chinese history. Furthermore, these documents include abundant descriptions, and the differentiation expressed by the semantics of the words and phrases indicate differences in the intensity and scope of events (Zhang, 1996a,b). These records also have been well accepted as one of the most important proxy resources in paleoclimatic reconstruction (Chu, 1973; CMA, 1981; Zhang, 1988; Zheng et al., 2006; Ge et al., 2010; 2013b). Researchers have successfully demonstrated the feasibility and reliability of using historical records and descriptions to reconstruct many facets of past social economies (Su et al., 2014; Wei et al., 2014, 2015; Yin et al., 2015).

In this paper, our study period spans from 210 BC to AD 1910 Based on historical documents and authoritative descriptions of Chinese history, using the Semantic Differential technique, we have attempted to reconstruct a quantitative social vicissitudes series of the past $2000 \mathrm{yr}$ with a 10 -yr resolution to express the phase transition of the social fluctuations of dynasties in China and to analyze the relationship between climate change and social vicissitudes.

\section{Materials and methods}

\section{Records for social series}

To reconstruct the social vicissitude series, we extracted data from 29 books dealing with the history of China. Most of these books were written by leading Chinese scholars and published in the last $30 \mathrm{yr}$. These books include several authoritative works on China's general history (Twitchett and Fairbank, 1978-2009; Bai, 1989-1999; Zhang, 1991, 2001; Fan and Mei, 1994; Lv, 2005; Jian et al., 2009; Fu, 2010; Ge, 2011), economic history (Fu, 1981-1989; Li, 1988; Yan, 1989; Shi and Xiao, 1994; Zhu and Zheng, 1995; Zhao, 2002; Jiang, 2004; Wang, 2007; Zhou, 2007), peasants' burden history (Li, 1991), monetary history (Peng, 2007), and fiscal history (Zhou, 1981; Chen, 1991; Huang, 1999; Xiang, 2006; Sun and Qi, 2008). Many of these books have been accepted as required textbooks for university education or as essential references in academic research in China. All of these books have different levels of detail in their descriptions concerning the phase change of social rise and fall for a specific dynasty. Moreover, the records extracted from these books can inform our semantic analysis not only because they contain comprehensive original social resources but also because they provide the objective assessments of historical experts on the long-term relative social vicissitudes based on their systematic and extensive analyses of the original records.

In total, 1586 items of direct and proffered records have been collected from passages of the text in the books referred to above. All of the records can be classified into four classes based on the different descriptions (Table 1 ). Class 1 (CR1) refers to the records with descriptions of the dynastic peace and turbulence. Dynastic peace means a period with a unified social regime; conversely, dynastic turbulence means a period with a divisive social regime and social unrest in the central plains of China. Class 2 (CR2) refers to the records with descriptions of social rising and falling events. Social rising events include a dynasty period with a higher level of political, economic and cultural development, such as "Hanwu Flourishing Age (141-87 BC)" in the Han Dynasty, "Kaiyuan Flourishing Age (713-AD 741)" in the Tang Dynasty, and "Kangxi Flourishing Age (1684-AD 1772)" in the Qing Dynasty (Ge, 2011). Social falling events include events of dynastic destructions or separation and uprisings or wars, which severely influenced dynasty rule and led to its fall, such as "An Lushan Rebellion (755-AD 762)" in the Tang Dynasty (Ge, 2011). Class 3 (CR3) refers to records with the other descriptions of social vicissitudes, such as "Decline phenomenon in the late Western Han Dynasty (48 BC-AD 30)" (Ge, 2011). Class 4 (CR4) refers to records with descriptions of people's livelihood, economy, and agriculture.

The 1002 items of direct evidence include records related to social vicissitudes and the accompanying descriptions. The other 584 proffered items of evidence include records concerning the dynastic unified condition, people's livelihood, and the condition of the economy and agriculture (Table 1 ). The temporal resolutions of the records range from one year to dynasty scale; the minimum resolution was one year and the maximum resolution was $540 \mathrm{yr}$. Records with resolutions of $10-40 \mathrm{yr}$ accounted for $75.5 \%$ of the total (Fig. 1a). All of the study periods was covered by the records (Fig. 1b).

\section{Methods and steps in the reconstruction of a social vicissitudes sequence}

The Semantic Differential technique was first developed by Osgood (1957) to identify the emotional meaning of words. It is most widely used in linguistics and psychology because it is effective in indexing qualitative word descriptions, such as attitude measurement. The Semantic Differential is usually conducted using ratings on bipolar scales defined with contrasting adjectives (like good and bad, large and small) at each end (Osgood, 1957). Fang et al. (2014) expounded a methodology for quantifying social and economic series on the base of semantic differential. Semantic analysis has been successfully used to reconstruct long-term series of climate change indices (CMA, 1981; Zheng et al., 2006), grain harvests (Su et al., 2014; Yin et al., 2015), economy and finance (Wei et al., 2014, 2015) in China and has been demonstrated to be a suitable approach for converting the qualitative descriptions found in literary sources into quantitative data.

Based on the success of those previous studies, this study translates words that indicate social vicissitudes in documents into quantifiable indices. Using semantic analysis, the descriptions of social vicissitudes can be divided into five levels from 1 to 5 , which represent tumultuous time, falling time, normal time, rising time and prosperous time, respectively.

\section{Step 1: Assessment of dynastic peace and turbulence}

The ancient Chinese feudalistic society exhibited social fluctuations at different temporal scales and the main characteristic was 
Table 1

Classification of records for social vicissitudes.

\begin{tabular}{|c|c|c|c|}
\hline Classification of records (CR) & Details & Temporal resolution & Number of records \\
\hline CR1 & Descriptions of dynastic peace and turbulence & Dynasty scale & 124 \\
\hline CR2 & Direct description of social rising and falling events & Multi-decadal scale and imperial scales & 232 \\
\hline CR3 & Indirect description of social rising and falling & Multi-decadal scale and decadal scale & 770 \\
\hline CR4 & Description of people's livelihood, economy, and agriculture & Few years scale and decadal scale & 460 \\
\hline
\end{tabular}

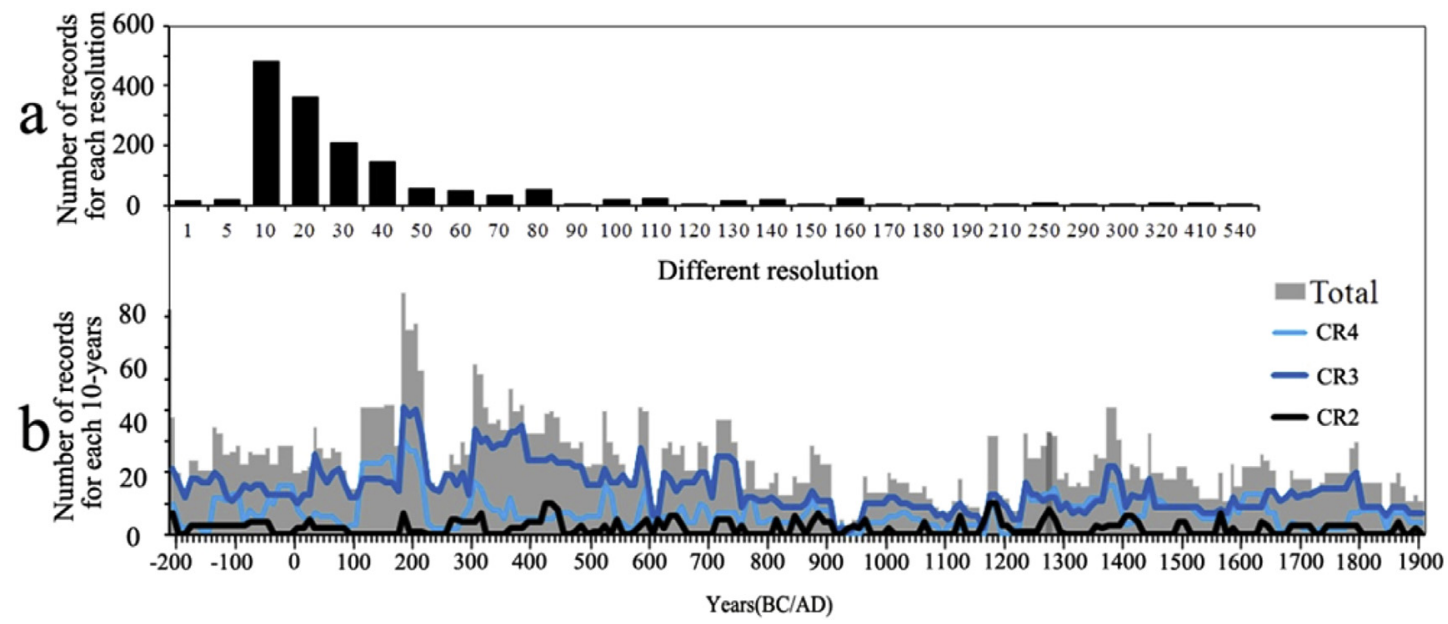

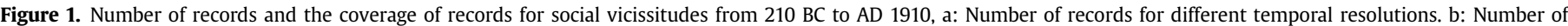

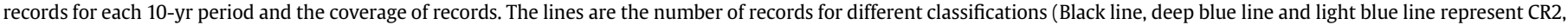

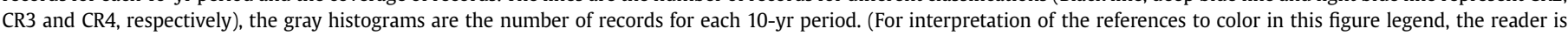
referred to the web version of this article.)

the cycle between the times of peace and turbulence (Ge, 2011; Zhang et al., 2015). Dynastic peace means a period with a unified social regime; conversely, dynastic turbulence means a period with a divisive social regime and social unrest in the central plains of China. According to the level of political and social order, the social conditions between dynastic peace and turbulence periods exhibited a significant difference, which can be used as the basis for the reconstruction of a social vicissitudes sequence.

CR1 (Table 1) was adopted as Step 1 and represents the peace and turbulence periods of China from 210 BC to AD 1910 (from the Western Han Dynasty to the Qing Dynasty) (Fig. 2). According to the content of CR1, the comprehensive conditions of the dynastic peace periods have been perceived as a higher level than the turbulence periods for the economy, politics and culture. The dynastic peace periods accounted for $68.4 \%$ of the total time in the study period (Table 2).

\section{Step2: Assessment of the direct descriptions for social vicissitudes}

The direct descriptions (CR2) of social vicissitudes were adopted for Step 2. A prosperous social system would be a stable one; otherwise, it would be unstable. Thus, the semantic meaning was used to describe the rising or prosperous time, and the vocabulary of the meaning process was used to describe times of falling prosperity or turmoil.

In Step 2, reviving, prosperous, or flourishing periods and dynastic destructions or separation and uprisings or wars, which have been widely acknowledged in China were adopted. According to the semantic differences of the CR2 records, the degree of dynastic prosperity or decline was distinguished and was divided into five types, as shown in Table 3.

On the basis of Step 1, distinguishing the dating of the records between the unification and division periods, records of type R1, R2, and R3, which occurred in a period of unification, were rated 5, 4, 3, respectively; those taking place during periods of division would be downgraded and respectively rated 4, 3, 3 (the lowest level was 3 ) (Fig. 2). On the other hand, the records of wars, insurrections, and rebellions of type $\mathrm{F} 1$ and $\mathrm{F} 2$, were respectively rated 2 and 1 (Table 4). After step 2, 98 decades (46.2\%) of social grades were preliminarily classified (Table 4 ).

Step 3: Assessment of the indirect descriptions for social vicissitudes

The indirect records in CR3 referred to the recapitulative descriptions in different time scales, which were characterized as reviving, prosperity or flourishing periods and dynastic destructions or separation events and uprisings or wars (Fig. 2). In Step 3, a multi-resolution fusion method (Fang et al., 2014; Wei et al., 2014, 2015) was adopted to improve the downscaling transformation. Specifically, for each original record that identified social changes, using groups of one hundred records, the different temporal resolutions were first integrated using the starting and ending times of the records, the time division of the relatively lowresolution records was gradually increased to $10 \mathrm{yr}$, and the decade was subsequently used as the basic time unit and the basis of the total processing (Table 5).

First, the evidence at 10 -yr resolutions that were downscaled in Step 3 was compared with the evidence of Step 2, and the evidence describing discrete situations was identified. The results can be divided into three categories: only Step 2 records, records that cooccur in both Step 2 and Step 3, and only Step 3 records. Second, for only the Step 2 records period, the social grade was identified as the grade for Step 2 (Table 6). Third, for the records that co-occurred in both the Step 2 and Step 3 periods, evidence of the degree and nature of the dynastic prosperity or decline was distinguished. The evidence of the nature of the dynastic prosperity or decline was defined as the change in the rising, normal, or falling condition. When the change was of the same nature and degree, the social 


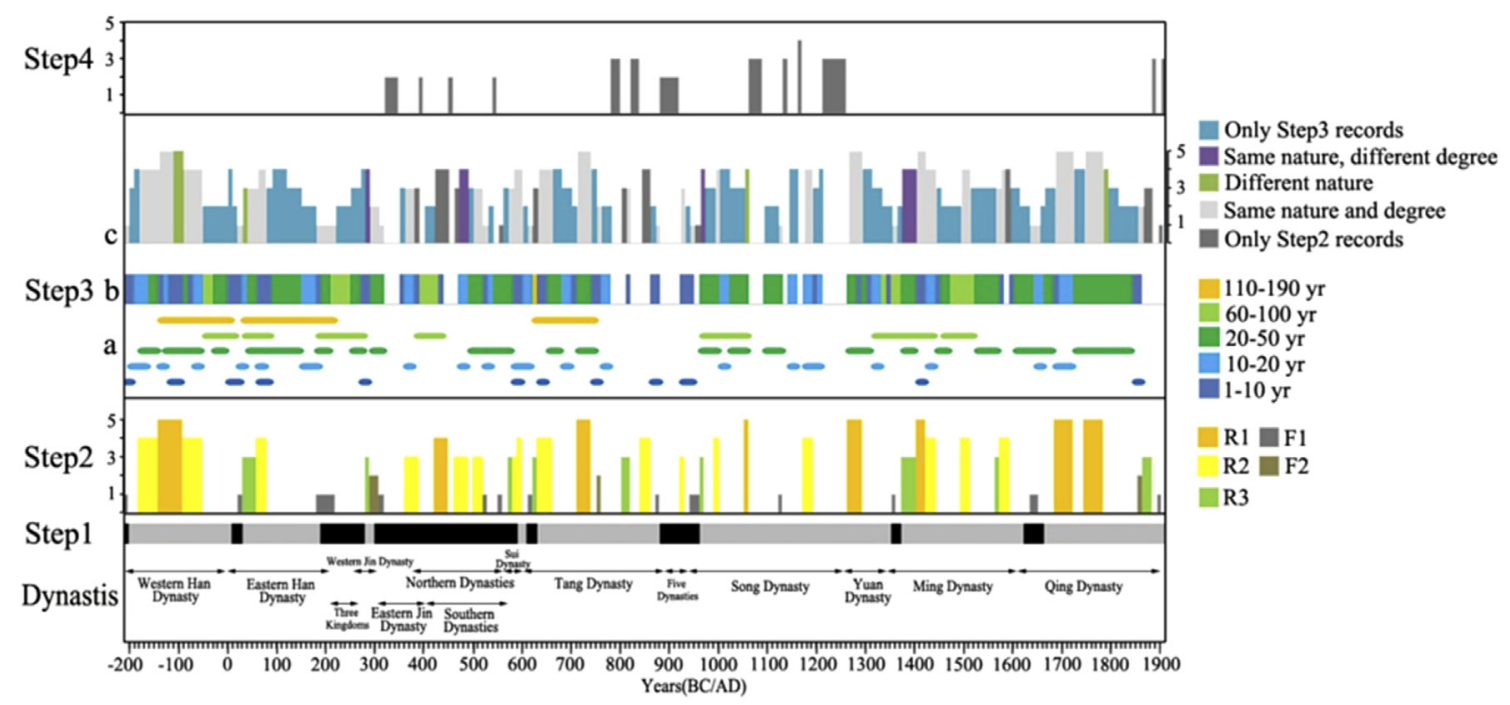

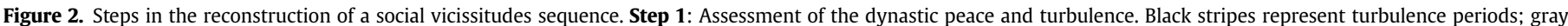

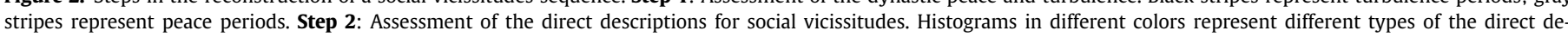

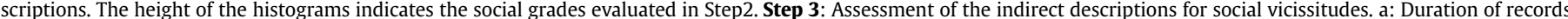

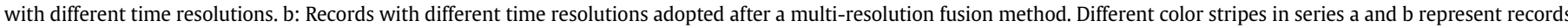

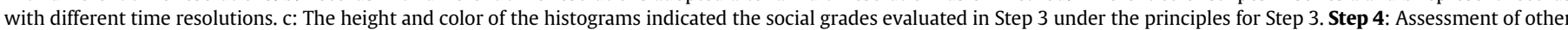
descriptions for social vicissitudes.

Table 2

Dynastic peace and turbulence periods of China from 210 BC to AD 1910 (Ge, 2011).

\begin{tabular}{|c|c|c|c|c|c|}
\hline \multicolumn{3}{|l|}{ Peace periods } & \multicolumn{3}{|c|}{ Turbulence periods } \\
\hline $\begin{array}{l}\text { Beginning and } \\
\text { ending time }\end{array}$ & Dynasty & $\begin{array}{l}\text { Duration } \\
\text { (years) }\end{array}$ & $\begin{array}{l}\text { Beginning and } \\
\text { ending time }\end{array}$ & Turbulence events & $\begin{array}{l}\text { Duration } \\
\text { (years) }\end{array}$ \\
\hline $202 \mathrm{BC}-\mathrm{AD} 9$ & West Han & 211 & 206 BC-202 BC & The War between Chu and Han. & 4 \\
\hline AD $25-183$ & East Han & 158 & AD 9-25 & WangMang usurpation. & 16 \\
\hline AD $280-304$ & West Jin & 25 & AD $184-280$ & $\begin{array}{l}\text { The yellow turban insurrectionary army uprising. } \\
\text { Separation of the Three Kingdoms. }\end{array}$ & 97 \\
\hline AD 589-611 & Sui & 22 & AD 304-589 & Separation of East Jin, sixteen Kingdoms and the northern and southern dynasties. & 286 \\
\hline AD $623-884$ & Tang & 261 & AD $611-623$ & Peasant uprisings and separation. & 12 \\
\hline AD 960-1279 & Song & 319 & AD $884-960$ & Separation of Five Dynasties and Ten Kingdoms. & 77 \\
\hline AD $1279-1354$ & Yuan & 75 & AD $1354-1372$ & Peasant uprisings and separation. & 18 \\
\hline AD $1372-1616$ & Ming & 244 & AD 1616-1661 & Nurhachi founded Late Jin Dynasty to fight against the Ming Dynasty and support peasant & 45 \\
\hline AD $1661-1911$ & Qing & 250 & & uprisings in the Late Ming Dynasty. & \\
\hline
\end{tabular}

Table 3

Types of the direct descriptions for social vicissitudes.

\begin{tabular}{|c|c|c|c|}
\hline & Types & Descriptions in CR2 & Periods \\
\hline \multirow[t]{13}{*}{ Rising } & \multirow[t]{4}{*}{$\mathrm{R} 1$} & Golden peak, the golden age; An unprecedented prosperity; & Hanwu Flourishing Age, Yuanjia Prosperity \\
\hline & & \multirow[t]{3}{*}{ Highly prosperous, prosperity apex } & Kaiyuan Flourishing Age, Jiayou Prosperity \\
\hline & & & Zhiyuan Prosperity, Yongle Flourishing Age \\
\hline & & & Kangxi Flourishing Age, Qianlong Flourishing Age \\
\hline & \multirow[t]{6}{*}{$\mathrm{R} 2$} & \multirow[t]{6}{*}{ Prosperity; Peace, happiness } & Wenjing Prosperity, Zhaoxuan Prosperity, Mingzhang Prosperity, Qianqin \\
\hline & & & Prosperity, Yongming Prosperity, Tianjian Prosperity \\
\hline & & & Jiande Prosperity, Kaihuang Prosperity, Zhenguan Prosperity \\
\hline & & & Yonghui Prosperity, Huichang Reviving, Dazhong Prosperity \\
\hline & & & Changxing Prosperity, Xianping Prosperity, Qianchun Prosperity, Renxuan \\
\hline & & & Prosperity, Hongzhi Reviving, Wanli Reviving \\
\hline & \multirow[t]{3}{*}{ R3 } & \multirow[t]{3}{*}{$\mathrm{R} 2$ which goes towards prosperity, or recovering from war } & Guangwu Reviving, Taikang Prosperity, Wude Prosperity \\
\hline & & & Yuanhe Reviving, Jianlong Prosperity, Hongwu Prosperity \\
\hline & & & Longqing Reviving, Tongzhi Reviving \\
\hline \multirow[t]{8}{*}{ Falling } & \multirow[t]{5}{*}{$\mathrm{F} 2$} & \multirow[t]{5}{*}{ War, insurrection to promote or accelerate dynasty downfall } & Peasant War of Qin, Chu-Han Struggle, Red eyebrow Uprising, Yellow Turbans \\
\hline & & & Uprising, Disruption of Eastern-Han, YongJia Turmoil \\
\hline & & & Liuzhen Turmoil, Houjing Turmoil, Wagang Peasant Uprising, Huangchao \\
\hline & & & $\begin{array}{l}\text { Uprising, Disruption of Five Dynasties and Ten States, Jikang Calamity, Red } \\
\text { towel Peasant Uprising }\end{array}$ \\
\hline & & & Li Zicheng Peasant Uprising, Yihetuan Movement \\
\hline & \multirow[t]{3}{*}{ F1 } & \multirow{3}{*}{$\begin{array}{l}\text { War, rebellion, etc., which severely influenced dynasty rule and } \\
\text { led to its turning point }\end{array}$} & Upheaval of the Eight Princes \\
\hline & & & An Lushan Rebellion \\
\hline & & & Taiping Rebellion \\
\hline
\end{tabular}


Table 4

Principle and statistics for Step 2.

\begin{tabular}{llllll}
\hline \multirow{2}{*}{ Step 1 } & \multicolumn{3}{l}{ Step 2 } & & \\
\cline { 2 - 6 } & Types & Grade & Principle & Number of decade & Percent/\% \\
\hline Unification & R1 & 5 & Prosperous time & 23 & 10.8 \\
& R2 & 4 & Rising time & 25 & 12.3 \\
& R3 & 3 & Normal time & 14 & 6.6 \\
Division & R1 & 4 & Rising time & 3 & 1.4 \\
& R2 & 3 & Normal time & 10 & 4.7 \\
& R3 & 3 & Normal time & 1 & 0.0 \\
& F2 & 2 & Falling time & 4 & 1.9 \\
& F1 & 1 & Turmoil time & 18 & 8.5 \\
\hline
\end{tabular}

Table 5

Statistics for the resolutions of records in Step 3.

$\begin{array}{lrllllllrrrrr}\text { Scale/year } & 10 & 20 & 30 & 40 & 50 & 60 & 70 & 100 & 110 & 130 & 150 & 190 \\ \text { Decades } & 45 & 50 & 30 & 36 & 20 & 18 & 21 & 20 & 11 & 13 & 15 & 19\end{array}$

grade was identified as Step 2. When the change was of the same nature but different in degree, the social grade was identified as Step 2 with a potential rise or drop of 1 grade. When the change was different in nature, it was categorized as Step 2 rising, the social grade was identified as Step 2 to drop 1 grade. When the change was of a different nature, the grade of Step 2 was normal; the social grade was identified as Step 2 . When the change was of a different nature, the grade of Step 2 was falling, the social grade was identified as Step 2 to rise or drop 1 grade (Table 6). Fourth, for only the Step 3 period records, the social grade was identified based on the nature of the evidence in Table 6. The Step 3 specific rating process, principles, and results are shown in Table 6. After comparing the results of the fusion of evidence, Step 3 resulted in 186 decades of evaluation and accounted for $87.7 \%$ of the entire time that was evaluated.

Step 4: Assessment of other descriptions for social vicissitudes

The records remaining after Step 3 that did not involve the specification of social grades, were evaluated by CR4 records, which were specific descriptions of people's livelihood, economy, and agriculture, etc (Fig. 2). Distinguishing the evidence between the unification and division periods, the nature of the evidence, the specific rating process, the principle, and the results for Step 4 are shown in Table 7. Through the above steps, we reconstructed a quantitative series of the social vicissitudes of the past $2000 \mathrm{yr}$ with a $10-y r$ resolution.

\section{Data for climate change}

Reconstructed climate series with a high-resolution that span longer than one millennium and range from regional to global have
Table 7

Process and principles for Step 4.

\begin{tabular}{lllcl}
\hline Step1 & Step5 & & & \\
\cline { 2 - 5 } & Nature of evidence & Principle & Decade & Percent/\% \\
\hline \multirow{2}{*}{ Unification } & Rising & Grade 4 & 1 & 0.5 \\
& Normal & Grade 3 & 15 & 7.1 \\
& Falling & Grade 3 & 0 & 0 \\
Division & Rising & Grade 3 & 0 & 0 \\
& Normal & Grade 2 & 0 & 0 \\
& Falling & Grade 2 & 10 & 4.7 \\
\hline
\end{tabular}

been generated by many researchers (e.g. Yang et al., 2002; Tan et al., 2003; Solomon, 2007; Loehle and McCulloch, 2008; Mann et al., 2009; Ge et al., 2010, 2013b; Tan et al., 2011; Christiansen and Charpentier Ljungqvist, 2012).

In China, since Chu (1973) reconstructed the temperature sequence of the past $5000 \mathrm{yr}$ based on historical documents, temperature changes in China have been continuously assessed and revised. At present, among the China temperature change sequences of the past $2000 \mathrm{yr}$, WCT.G (Ge et al., 2013b), which is reconstructed by principal component regression (PCR) and partial least squares regression (PLS) from 28 temperature proxies (lake sediments, stalagmite, ice cores, tree rings and historical records) with reference to the 1851-1950 climatology, at a decadal resolution, covering the whole of China for the past $2000 \mathrm{yr}$ is widely recognized and shared (Table 8 ). In particular, ECT.G for eastern China can explain 70\% of the variance in WCT.G (Ge et al., 2013b). Because eastern China has long been the center of economic activity, this region is the most important source of central government revenues (Fig. 3). Thus, this series is more suitable for use in the present study. In addition, WCT.Y is another typical China-wide temperature sequence covering the past $2000 \mathrm{yr}$ which was established by combining multiple paleoclimate proxy records obtained from ice cores, tree rings, lake sediments and historical documents (Yang et al., 2002; Table 8).

For precipitation changes, ECP.Z was the only available $2000-\mathrm{yr}-$ long decadal precipitation series that covered the entire region of eastern China (Zheng et al., 2006). Moreover, for eastern China, there was considerable regional variation in precipitation among the Northern China Plain, the Jiang-Huai area and the Jiang-Nan area (Zheng et al., 2006). Thus, four precipitation series in these three sub-regions (Fig. 3) of eastern China were selected to test their relation to the imperial social vicissitudes (Table 8). ECP.Z, NCP.Z, JHP.Z and JNP.Z were all reconstructed from historical documents by Zheng et al. (2006). All of these series are decadal, with a moving average of each year from $133 \mathrm{BC}$ to AD 2000. NCP.T is a decadal resolution precipitation series spanning the last $1800 \mathrm{yr}$ (AD 190-1980) which was reconstructed from high-resolution precisely-dated stalagmite records and historical documents from north central China (Table 8).

Table 6

Process and principles for Step 3.

\begin{tabular}{|c|c|c|c|}
\hline \multicolumn{3}{|l|}{ Step 3} & \multirow[t]{2}{*}{ Decades } \\
\hline Evidence covering & Compare the nature and degree of evidence & Principle & \\
\hline Only Step 2 records & & Grade of Step 2 & 15 \\
\hline \multirow[t]{5}{*}{ Records co-occurring in Step 2 and Step 3} & Same nature and degree & Grade of Step 2 & 71 \\
\hline & Same nature, different degree & Grade of Step 2 to rise or drop 1 grade & 7 (all rise 1 grade) \\
\hline & Different nature, grade of Step 2 was rising & Grade of Step 2 to drop 1 grade & 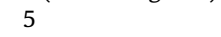 \\
\hline & Different nature, grade of Step 2 was normal & Grade of Step 2 & 0 \\
\hline & Different nature, grade of Step 2 was falling & Grade of Step 2 to rise 1 grade & 0 \\
\hline \multirow[t]{3}{*}{ Only Step 3 records } & Rising & Grade 4 & 18 \\
\hline & Normal & Grade 3 & 32 \\
\hline & Falling & Grade 2 & 38 \\
\hline
\end{tabular}


Table 8

Climate indexes used in this study.

\begin{tabular}{|c|c|c|c|c|c|c|c|}
\hline Name & Label & Site & Proxy type & Resolution & Seasonality & Period (BC/AD) & Reference \\
\hline \multirow[t]{3}{*}{ Temperature } & WCT.G & Whole China $\left(23^{\circ}-42^{\circ} \mathrm{N}, 80^{\circ}-127^{\circ} \mathrm{E}\right)$ & Multi-proxies & Decadal & Annual & $1-1990$ & Ge et al. (2013) \\
\hline & ECT.G & Eastern China $\left(31^{\circ}-38^{\circ} \mathrm{N}, 110^{\circ}-120^{\circ} \mathrm{E}\right)$ & Historical documents & 3-decadal & Winter-spring & (BC) $210-1910$ & Ge et al. (2010) \\
\hline & WCT.Y & Whole China $\left(23^{\circ}-42^{\circ} \mathrm{N}, 80^{\circ}-127^{\circ} \mathrm{E}\right)$ & Multi-proxies & Decadal & Annual & $1-2000$ & Yang et al. (2002) \\
\hline \multirow[t]{5}{*}{ Precipitation } & ECP.Z & Eastern China $\left(25^{\circ}-40^{\circ} \mathrm{N}, 105^{\circ}-121^{\circ} \mathrm{E}\right)$ & $\begin{array}{l}\text { Historical documents, } \\
\text { mean of } 48 \text { stations }\end{array}$ & Decadal & Spring-autumn & $105-2000$ & Zheng et al. (2006) \\
\hline & NCP.Z & North China Plain $\left(34-40^{\circ} \mathrm{N}, 105^{\circ}-121^{\circ} \mathrm{E}\right)$ & Mean of 21 stations & Decadal & Spring-autumn & (BC) $133-2000$ & Zheng et al. (2006) \\
\hline & JHP.Z & Jiang-Huai area $\left(31-34^{\circ} \mathrm{N}, 110^{\circ}-121^{\circ} \mathrm{E}\right)$ & Mean of 10 stations & Decadal & Spring-autumn & $13-2000$ & Zheng et al. (2006) \\
\hline & JNP.Z & Jiang-Nan area $\left(25-31^{\circ} \mathrm{N}, 110^{\circ}-121^{\circ} \mathrm{E}\right)$ & Mean of 17 stations & Decadal & Spring-autumn & $105-2000$ & Zheng et al. (2006) \\
\hline & NCP.T & North China Plain $\left(33-42^{\circ} \mathrm{N}, 104^{\circ}-121^{\circ} \mathrm{E}\right)$ & Multi-proxies & Decadal & Annual & $190-1980$ & Tan et al. (2011) \\
\hline
\end{tabular}

Analysis of the relationship between climate change and social vicissitudes

The relationship between climate change and social vicissitudes was analyzed as follows:

(1) The stage characteristics of social vicissitudes were analyzed by calculating the mean value of the social grade; the periodic vicissitudes of the social fluctuations were analyzed by wavelet analysis.

(2) The correlation between climate changes (WCT.G, ECT.G, WCT.Y, ECP.Z, NCP.Z, JHP.Z, JNP.Z, and NCP.T) and social vicissitudes was analyzed by Pearson correlations.

(3) The periodic bands between climate changes (WCT.G, and ECP.Z) and social vicissitudes were analyzed by wavelet coherence.

(4) The relationship between climate series (WCT.G and ECP.Z) and social vicissitudes was analyzed by grouping the temperature (WCT.G) and precipitation (ECP.Z) conditions, then comparing the differences of the average social grades in different temperature-precipitation combination types.

\section{Results}

Characteristics of the social vicissitudes from 210 BC to AD 1910

The reconstructed social vicissitudes sequence has 212 decadal grades, and the percentage of each grade is shown in Table 9. Level 3 has the largest percentage $(30.2 \%)$ relative to that of the other levels. As displayed in Figure 4, the social grades clearly fluctuated from $210 \mathrm{BC}$ to AD 1910 and went through several long stages.

The mean value for seven major stages was determined (Table 10 and Fig. 4) at the century-scale. The stages that featured relative social rising were distributed from $210 \mathrm{BC}$ to $\mathrm{AD} 150, \mathrm{AD}$ 581 to AD 860, AD 1371 to AD 1910, respectively, with the mean level equal to or above 3. Levels $4-5$ accounted for at least $40.7 \%$ of the levels, with a maximum percentage of $55.6 \%$ from $210 \mathrm{BC}$ to AD 150. The average percentage of levels $4-5$ for the three periods (46.7\%) was approximately $26.9 \%$ higher than the average percentage from $210 \mathrm{BC}$ to $\mathrm{AD} 1910$ (36.8\%). In comparison, the periods from $A D 151$ to $A D 580$ and $A D 861$ to $A D 1370$ were times of relative social falling, with the mean level at approximately 2.3 . The percentage of levels $1-2$ ranged from $33.3 \%$ to $58.8 \%$. The mean

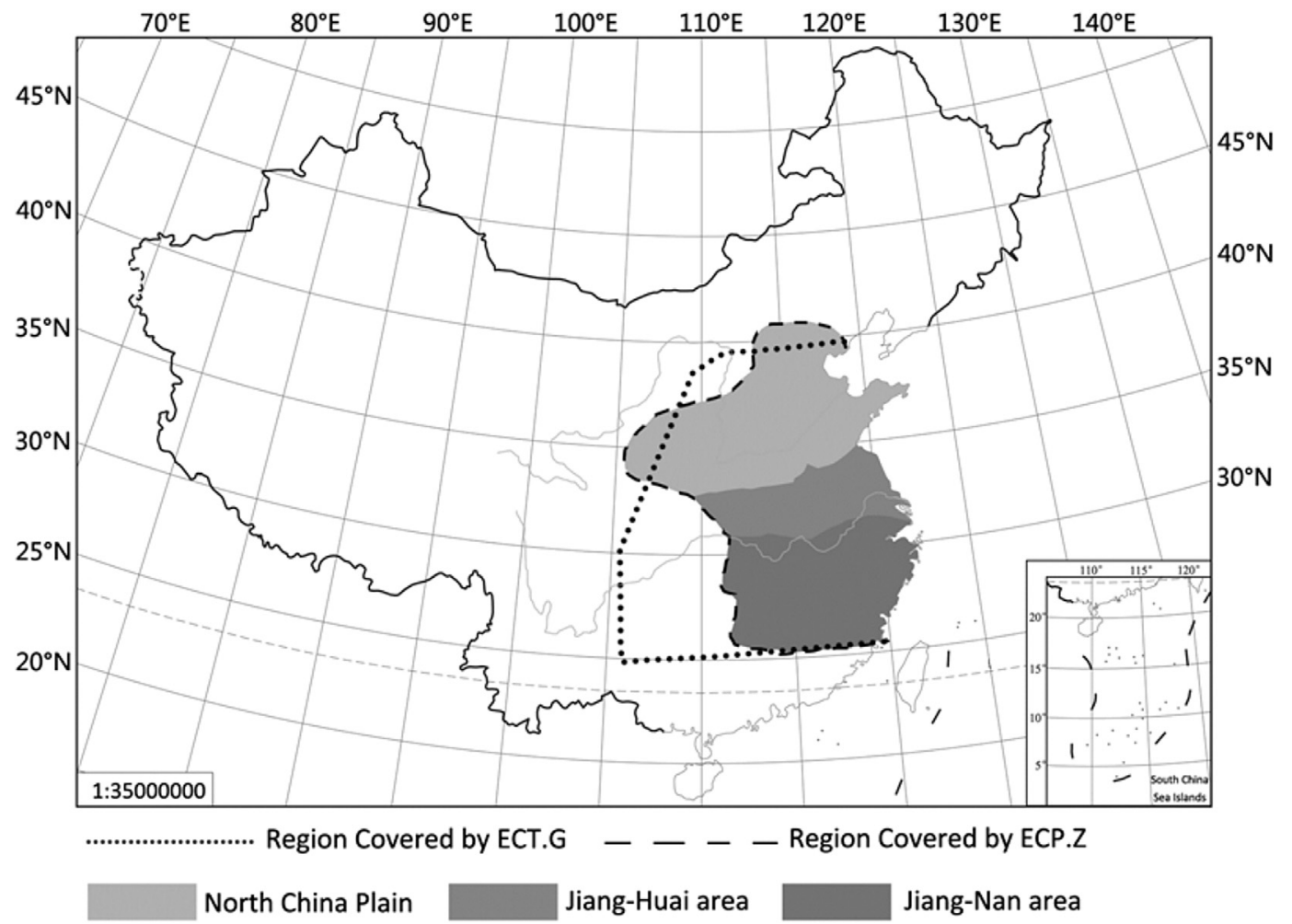

Figure 3. Location of climate indexes used in this study. 
Table 9

Distribution of social grades from 210 BC to AD 1910.

\begin{tabular}{llcccc}
\hline Grade & 1 & 2 & 3 & 4 & 5 \\
\hline Years & 180 & 520 & 640 & 570 & 210 \\
Percentage (\%) & 8.5 & 24.5 & 30.2 & 26.9 & 9.9 \\
\hline
\end{tabular}

percentage of the two periods was $43.6 \%$, which is $32 \%$ higher than the average value from $210 \mathrm{BC}$ to AD 1910 (33\%).

In each major stage, there were several secondary-stage fluctuations of social grades, which lasted $50-250 \mathrm{yr}$ on average (Table 10). Based on the means of the secondary stages, the most prosperous periods were from $210 \mathrm{BC}$ to $51 \mathrm{BC}$ (the Middle of the Western Han Dynasty), AD 581 to AD 750 (the Sui Dynasty to the Middle of the Tang Dynasty), AD 1661 to AD 1810 (the Middle of the Qing Dynasty), respectively, with the mean level above 3.5. In comparison, the periods from AD 151 to AD 350 (the Late Eastern Han Dynasty), AD 521 to AD 580 (the Late Southern and Northern Dynasties), AD 861 to AD 960 (the Late Tang Dynasty to Five Dynasties), AD 1091 to AD 1140 (the Late Northern Song Dynasty to Early Southern Song Dynasty), AD 1331 to AD 1370 (the Late Yuan Dynasty) and AD 1661 to AD 1660 (the Late Ming Dynasty) were characterized by social falling, with the mean value below 2 .

The major and secondary stages indicate that the main social rising periods primarily occurred during the earlier stage of several powerful unified dynasties, some of which are well accepted as the most prosperous economically and the strongest in state power.

The continuous wavelet power spectra analysis showed social grade series exhibit periodicities of $40 \mathrm{yr}$ from AD 400 to AD 900, periodicities of $80 \mathrm{yr}$ from AD 500 to AD 800, periodicities of $100 \mathrm{yr}$ from $A D 1100$ to $A D 1700$, and periodicities of 160-200 yr around AD 100 and AD 1500, respectively (Fig. 5).

\section{Relationship between climate change and social vicissitudes}

The series comparison in Figure 6 showed that the centennial change in temperature displayed relatively consistent coincidences with the stage fluctuations in the social vicissitudes. Essentially, the relatively social rising stages coincided with a relatively warmer climate, and the relatively social falling stages coincided with a relatively colder climate. For the precipitation of eastern China, a stage of social falling usually coincided with reduced precipitation (Fig. 6).

The results of the correlation analysis showed that the social grade fluctuations are positively correlated with both the temperature change and the precipitation change in China (Table 11). Further, the results also showed positive associations between social states and temperature reconstructions with different units of spatial coverage, from the regional (Table 11, ECT.G: eastern China), to whole of China (Table 11, WCT.G and WCT.Y), at different time scales for the past $2000 \mathrm{yr}$. There was also a significant positive
Table 10

Percentage of each social grade during the five stages from 220 BC to AD 1910.

\begin{tabular}{|c|c|c|c|c|c|}
\hline Major stages & Grade mean & Years & Secondary stages & Grade mean & Years \\
\hline \multirow[t]{3}{*}{210 BC-AD 150} & 3.42 & 360 & $210-51 \mathrm{BC}$ & 4.06 & 160 \\
\hline & & & 50BC-AD 30 & 2.13 & 80 \\
\hline & & & AD 31-150 & 3.42 & 120 \\
\hline \multirow[t]{3}{*}{ AD 151-580 } & 2.44 & 430 & AD 151-350 & 2 & 200 \\
\hline & & & AD $351-520$ & 3.06 & 170 \\
\hline & & & AD 521-580 & 2 & 60 \\
\hline \multirow[t]{2}{*}{ AD 581-860 } & 3.32 & 280 & AD 581-750 & 3.59 & 170 \\
\hline & & & AD 751-860 & 2.83 & 120 \\
\hline \multirow[t]{5}{*}{ AD 861-1370 } & 2.94 & 510 & AD 861-960 & 1.78 & 90 \\
\hline & & & AD 960-1090 & 3.38 & 130 \\
\hline & & & AD $1091-1140$ & 2 & 50 \\
\hline & & & AD $1141-1330$ & 3.74 & 190 \\
\hline & & & AD $1331-1370$ & 1.75 & 40 \\
\hline \multirow[t]{4}{*}{ AD 1371-1910 } & 3.26 & 540 & AD 1371-1610 & 3.38 & 240 \\
\hline & & & AD 1611-1660 & 1.6 & 50 \\
\hline & & & AD 1661-1810 & 4.27 & 150 \\
\hline & & & AD 1811-1910 & 2.3 & 100 \\
\hline
\end{tabular}

relationship between social states and precipitation in eastern China (Table 11, ECP.Z). The correlations between social states and precipitation in Northern and Central China (Table 11, NCP.Z, JHP.Z and NCP.T) were more significant than those in Southern China (Table 11, JNP.Z). In comparison, temperature displayed a stronger association with the social vicissitudes at different time scales from short-term variation to long-term trend, which indicated that longterm social vicissitudes were more significantly driven by longterm temperature change at 30-90 yr scales (Table 11). This is consistent with the impact of temperature on the fluctuation of population in central China (Lee and Zhang, 2010), and macroeconomic cycles in pre-industrial Europe (Pei et al., 2014). The correlation between precipitation and social vicissitudes was stronger at the short-term with 10-30 yr scales, which implied that the social vicissitudes were more responsive to short-term precipitation oscillations. These results further quantitatively confirmed that links exist between climate change and the empire's vicissitudes. The above associations are amplified on the longer time scale.

The wavelet coherence analysis shows there are great overlaps between social and climatic variables around the predominant or periodic bands (Fig. 7). Social grade had a very good match with temperature at the 3 periodic bands of 100,200 , and $320 \mathrm{yr}$, and the $100 \mathrm{yr}$ periodic bands appeared over AD 1000-1600, the $200 \mathrm{yr}$ periodic bands appeared over AD 1200-1500, the $300 \mathrm{yr}$ periodic bands appeared over AD 400-1600, respectively. Social grade had a very good match with precipitation at the 2 periodic bands of 40-80 and $120-160 \mathrm{yr}$; the $40-80 \mathrm{yr}$ periodic bands appeared over AD 200-1800, the 120-160 yr periodic bands appeared over AD 1100-1700, respectively. Temperature showed predominant and consistent in-phase associations with social vicissitudes around the 3 periodic bands of 100, 200, and $320 \mathrm{yr}$ (Fig. 7a).

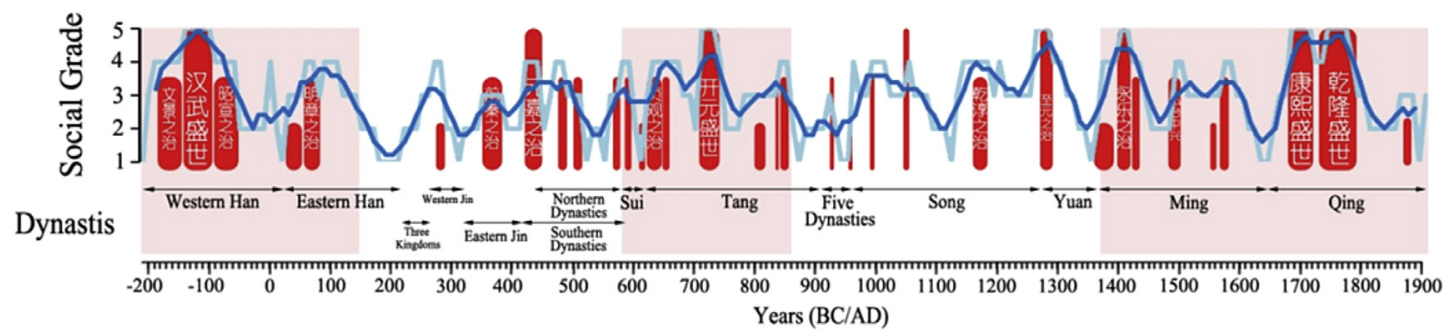

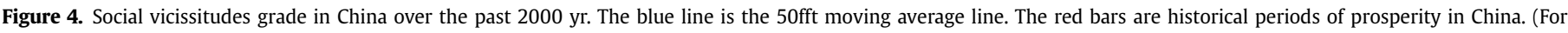
interpretation of the references to color in this figure legend, the reader is referred to the web version of this article.) 


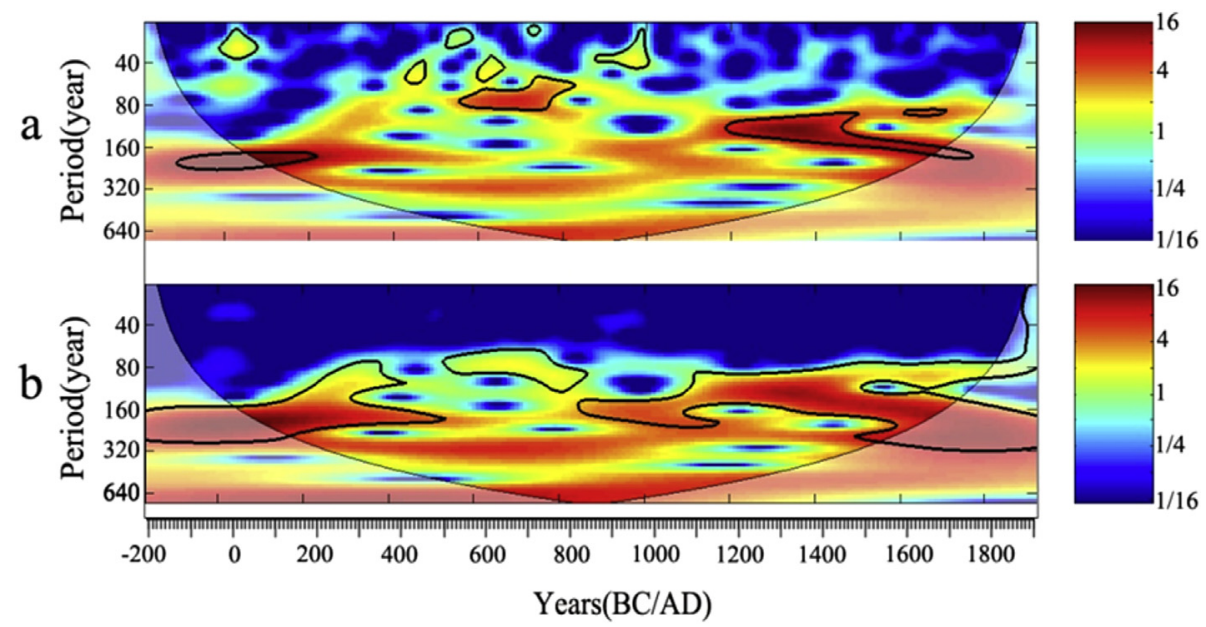

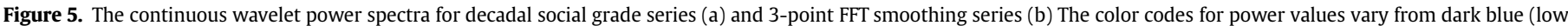

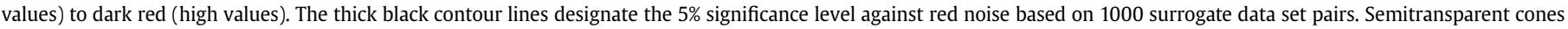
indicate the regions influenced by edge effects. (For interpretation of the references to color in this figure legend, the reader is referred to the web version of this article.)

Whereas precipitation showed predominant in-phase associations around the 120-160 yr bands, out-of-phase associations were evident around the $40-80 \mathrm{yr}$ bands during the periods AD 1000-1200 and AD 1600-1800.

To further compare their temporal synchronisation, we defined the temperature (WCT.G; Table 12) anomaly $\geq 0^{\circ} \mathrm{C}$ and $<0^{\circ} \mathrm{C}$ as warm and cold periods, respectively, and defined the precipitation index (ECP.Z; Table 12) as $<-0.1,-0.1$ to 0.35 and $>0.35$ as dry, moderate and wet periods, respectively (Su et al., 2014).
A warmer climate was more beneficial to social rise than a colder climate, as indicated by the mean values and percentages of grade. In the warm periods, the mean value of the social grade (3.24) was higher than the average value from 210 BC to AD 1910 (3.05), and the percentage of levels $4-5$ was $44.3 \%$, but the percentage of levels $1-2$ was $24.5 \%$. In the cold periods, the mean value of the social grade (2.86) was lower than the average value from 210 BC to AD 1910, and the percentage of levels $1-2$ was $41.5 \%$, and the percentage of levels $4-5$ was $29.2 \%$. Further, the coefficient of

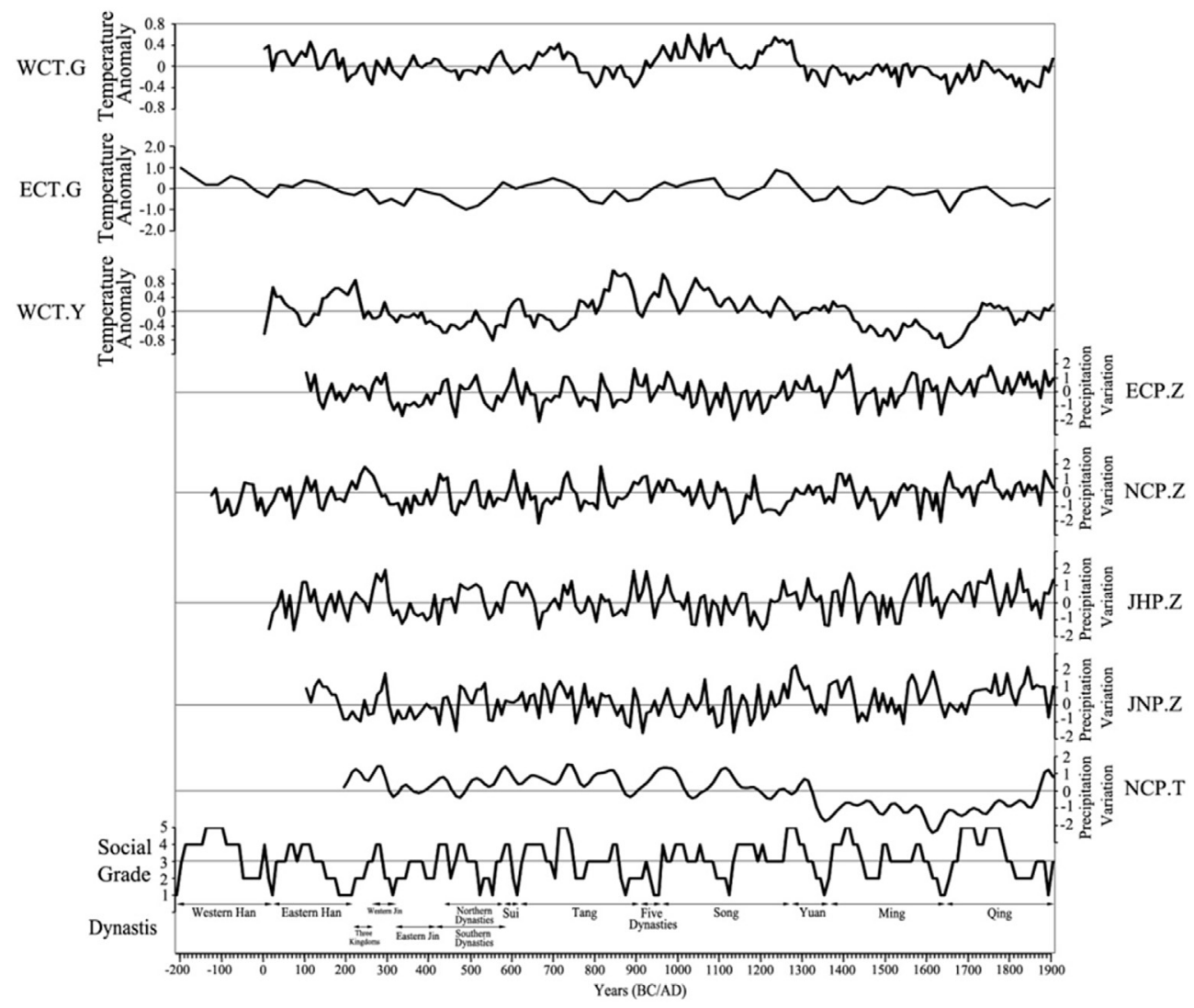

Figure 6. Climate series cited to compare with the social grade over the past $2000 \mathrm{yr}$. 
Table 11

Pearson correlations between climate change and social vicissitudes.

\begin{tabular}{|c|c|c|c|c|c|}
\hline \multirow[t]{2}{*}{ Index } & \multirow[t]{2}{*}{ Region } & \multirow[t]{2}{*}{ Original series } & \multicolumn{3}{|c|}{ Smoothing series } \\
\hline & & & 3-point FFT & 9-point FFT & 15-point FFT \\
\hline WCT.G & Whole of China & $0.166^{* *}$ & $0.201^{* * *}$ & $0.188^{* *}$ & $0.085^{*}$ \\
\hline ECT.G & Eastern China & - & $0.339^{* * *}$ & $0.402^{* *}$ & $0.357^{* *}$ \\
\hline WCT.Y & Whole of China & $0.07^{*}$ & $0.103^{* *}$ & $0.189^{* *}$ & $0.280^{*}$ \\
\hline ECP.Z & Eastern China & $0.195^{* * *}$ & $0.273^{* *}$ & $0.223^{*}$ & 0.200 \\
\hline NCP.Z & Northern China & $0.289^{* *}$ & $0.412^{* *}$ & $0.472^{*}$ & 0.575 \\
\hline JHP.Z & Central China & $0.203^{* *}$ & $0.255^{* *}$ & $0.201^{*}$ & 0.169 \\
\hline JNP.Z & Southern China & $0.075^{*}$ & $0.102^{*}$ & -0.044 & -0.168 \\
\hline NCP.T & Northern China & $0.142^{* *}$ & $0.183^{*}$ & $0.274^{*}$ & 0.397 \\
\hline
\end{tabular}

${ }^{* * *}: \mathrm{P}<0.01 ;{ }^{* *}: \mathrm{P}<0.05 ;{ }^{*}: \mathrm{P}<0.1$
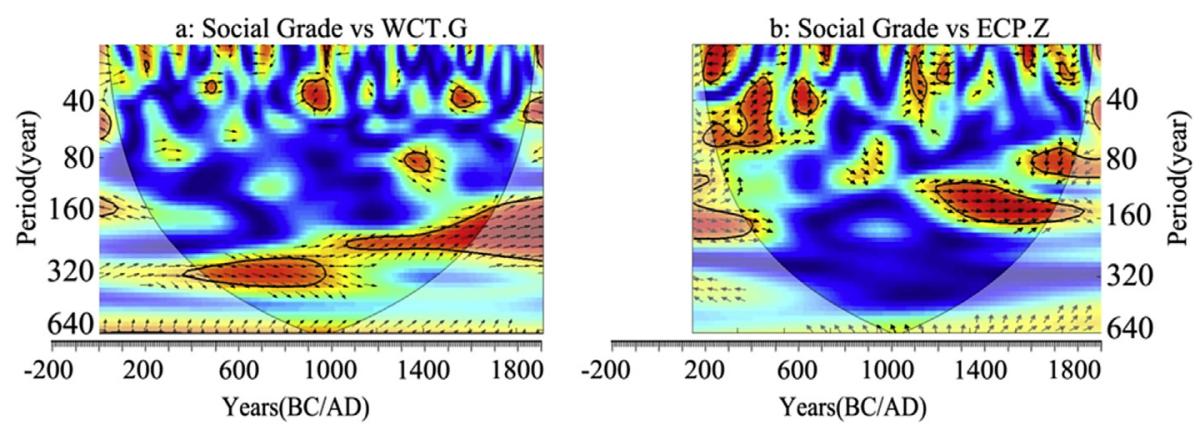

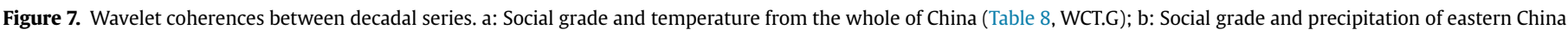

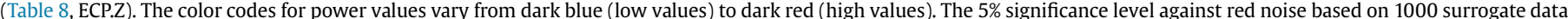

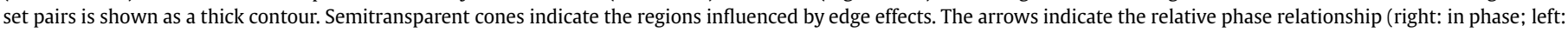
out-of-phase). (For interpretation of the references to color in this figure legend, the reader is referred to the web version of this article.)

variation in cold periods was larger (Table 12), showing that the social grades were more unstable in cold climate periods compared to warm climate periods.

A wetter climate benefited social rising much more than a drier climate. In the wet periods, the mean value of the social grade was 3.20 ; while in the moderate and dry periods, the mean value of social grade was 3.03 and 2.84 , respectively. The coefficient of variation in dry periods was larger (Table 12), showing that the social grades were more unstable in a dry climate than wetter climate.

By calculating the mean values of the social grades corresponding to the different temperature-precipitation combinations, six temperature-precipitation combinations were obtained (Table 12). The mean social grade value ordered from high to low was as follows: warm-wet (3.67), warm-moderate (3.14), warm-dry (3.13), cold-wet (2.95), cold-moderate (2.83) and cold-dry (2.44).

Table 12

Social grades under different climatic scenarios.

\begin{tabular}{|c|c|c|c|c|c|c|c|c|c|}
\hline \multirow[t]{2}{*}{ Climatic scenarios } & \multirow[t]{2}{*}{ Grade no. } & \multirow[t]{2}{*}{ Mean } & \multirow[t]{2}{*}{ SD (standard deviation) } & \multirow[t]{2}{*}{ CV (coefficient of variation) } & \multicolumn{5}{|c|}{ Percentage of each grade } \\
\hline & & & & & 1 & 2 & 3 & 4 & 5 \\
\hline All & 212 & 3.05 & 1.12 & 0.37 & 8.49 & 24.53 & 30.19 & 26.89 & 9.91 \\
\hline $\mathrm{T} \geq 0$ & 106 & 3.24 & 1.07 & 0.33 & 6.60 & 17.92 & 31.13 & 33.96 & 10.38 \\
\hline $\mathrm{T}<$ & 106 & 2.87 & 1.14 & 0.40 & 10.38 & 31.13 & 29.25 & 19.81 & 9.43 \\
\hline$P>0.35$ & 66 & 3.20 & 1.07 & 0.33 & 3.03 & 25.76 & 33.33 & 24.24 & 13.64 \\
\hline$-0.1<\mathrm{P}<0.35$ & 31 & 3.03 & 1.11 & 0.37 & 9.68 & 22.58 & 29.03 & 32.26 & 6.45 \\
\hline $\mathrm{P}<-0.1$ & 80 & 2.84 & 1.11 & 0.39 & 12.50 & 26.25 & 32.50 & 22.50 & 6.25 \\
\hline
\end{tabular}

Table 13

Social grades under different climatic combinations.

\begin{tabular}{|c|c|c|c|c|c|c|c|c|c|}
\hline \multirow[t]{2}{*}{ Climatic combinations } & \multirow[t]{2}{*}{ Percentage } & \multirow[t]{2}{*}{ Mean } & \multirow[t]{2}{*}{ Max } & \multirow[t]{2}{*}{ Min } & \multirow[t]{2}{*}{ SD } & \multirow[t]{2}{*}{$\mathrm{CV}$} & \multicolumn{3}{|c|}{ Percentage of each grade } \\
\hline & & & & & & & $1-2$ & 3 & $4-5$ \\
\hline Warm-wet & 15.00 & 3.67 & 5 & 2 & 1.00 & 0.27 & 11.11 & 33.33 & 55.56 \\
\hline Warm-moderate & 11.67 & 3.14 & 5 & 1 & 1.07 & 0.33 & 28.57 & 28.57 & 42.86 \\
\hline Warm-dry & 16.67 & 3.13 & 4 & 2 & 1.14 & 0.40 & 20.00 & 60.00 & 20.00 \\
\hline Cold-wet & 21.67 & 2.95 & 4 & 2 & 1.07 & 0.33 & 30.77 & 30.77 & 38.46 \\
\hline Cold-moderate & 10.00 & 2.83 & 5 & 1 & 1.11 & 0.37 & 66.67 & 11.11 & 22.22 \\
\hline Cold-dry & 25.00 & 2.44 & 4 & 1 & 1.11 & 0.39 & 66.67 & 20.00 & 13.33 \\
\hline
\end{tabular}


Under warm-wet conditions, the grade of social rise (Grade 4 and Grade 5) was over 55.56\%; under cold-dry conditions, the grade of social fall (Grade 2 and Grade 1 ) was over $66.67 \%$. This result further confirmed that social rise primarily occurred in warm-humid climate conditions (Table 13).

\section{Discussion}

\section{Dynastic prosperity in China over the past $2000 \mathrm{yr}$}

From 210 BC to AD 1910 (from the Western Han Dynasty to the Qing Dynasty), the temperature change (ECT.G, Table 8) in China can be roughly divided into 6 phases (Ge et al., 2010). The 3 warm periods are: 210 BC to AD 180 (the Han Warm Period), AD 541-810 (the Sui-Tang Warm Period), and AD 931-1320 (the Song-Yuan Warm Period). The 3 cold periods are: AD 181-540 (the Wei, Jin, Northern and Southern Dynasties Cold Period), AD 811-930 (the Late Tang Cold Period), and AD 1321-1910 (the Ming-Qing Cold Period).

In Step 2, reviving, prosperous or flourishing periods which have been widely acknowledged in China were identified (Table 3). From $210 \mathrm{BC}$ to AD 1910, there were 34 dynastic reviving, prosperous or flourishing periods over a total of $695 \mathrm{yr}$ (Fig. 4, the red bars). 85.3\% of the dynastic reviving, prosperous or flourishing periods coincided with a warm climate, that includes 18 periods that occurred in warm periods and 11 periods in the relatively warm stages of a cold period. In addition, 26 dynastic reviving, prosperous or flourishing periods (76.5\%) occurred when the climate changed from cold to warm. It appears that the dynastic prosperity over the past $2000 \mathrm{yr}$ mostly coincided with warm periods or the periods that changed from cold to warm.

\section{Mechanisms for climatic effects}

Most conclusions regarding the impacts of climate change on human history have been derived from direct comparisons of historical climate change events and related social phenomena occurring during the same period (Lamb, 1995; Weiss and Bradley, 2001; Costanza et al., 2007; Nunn et al., 2007). A number of previous studies have identified climatic forcing as the main cause of the decline in ecological and agricultural resources, and climatic deterioration as the primary mechanism to link climate change and social crisis (deMenocal, 2001; Büntgen et al., 2011; Zhang et al., 2011). This can identify the mechanisms driving the impact of climate change on social vicissitudes in the present study, because as a country founded on the basis of agriculture, both the people's living standards and the comprehensive national strength in China relied on agriculture. Long-term climate change has significant direct effects on regional agricultural production (Galloway, 1986; Su et al., 2014; Yin et al., 2015), which in turn affects regional land carrying capacity. At an empire-wide scale, government-led regulation of food constituted the main aspect of economic life in ancient China (Wei et al., 2015). Consequently, the impacts of climate change could pass to the economic system through the impacts of climate change on the agricultural system (Fang et al., 2013). Nationwide economic depression and collapse would follow armed conflicts, wars and invasions which would bring large depopulation, migration, damage and abandonment of land and irrigation facilities, and fiscal crises (Wei et al., 2015), which ultimately may severely influenced dynasty rule and led to its collapse.

\section{Conclusions}

The relationship between climate change and historical rhythms has long been discussed; however, this type of study still faces the lack of high-resolution data concerning long-term socio-economic processes. We collected 1586 items of direct and proffered evidence from 29 Chinese history books. By analyzing the semantics of words (Semantic Differential technique) and integrating descriptions with multi-time resolution into the same decadal resolution, we reconstructed a quantitative series of the social vicissitudes of the past $2000 \mathrm{yr}$ with a 10-yr resolution to express the phase transition of the social vicissitudes of the dynasties in China.

Our reconstruction shows that social grade fluctuations during 210 BC to AD 1910 in China displayed cyclical changes. The association of social vicissitudes with climate changes indicates that temperature displayed more significant effects on social vicissitudes in the long term, while precipitation displayed more significant effects on the social vicissitudes in the short term. Social grade had a very good match with temperature at the 3 periodic bands of 100,200 , and $320 \mathrm{yr}$, and with precipitation at the 2 periodic bands of $40-80$ and $120-160 \mathrm{yr}$. Social rise mostly occurred in the centennial-scale warm periods, whereas social decline mostly occurred in the centennial-scale cold periods. Under warm-wet conditions, $t$ social rise occurred over $57 \%$ of the time; under cold-dry conditions, social decline occurred over $66 \%$ of the time.

\section{Acknowledgments}

This work was supported by National Natural Science Foundation of China (Grant No. 41371201), Strategic Project of Science and Technology of the Chinese Academy of Sciences (Grant No. XDA05080102), State Key Laboratory Of Environmental Change And Natural Disaster (Grant No. 2015jzhz11), and the Major State Basic Research Development Program of China (973 Program) (Grant No. 2010CB950103).

\section{References}

Amorosi, A., Bini, M., Giacomelli, S., et al., 2013. Middle to late Holocene environmental evolution of the Pisa coastal plain (Tuscany, Italy) and early human settlements. Quaternary International 33, 93-106.

Bai, S.Y., 1989-1999. The General History of China. Shanghai People's Publishing House, Shanghai.

Büntgen, U., Tegel, W., Nicolussi, K., et al., 2011. 2500 years of European climate variability and human susceptibility. Science 331 (6017), 578-582.

Chen, M.G., 1991. The New Financial History of the Tang Dynasty. China Financial and Economic Publishing House, Beijing.

Cheng, Hai, Edwards, R.L., Haug, G.H., 2010. Comment on "On linking climate to Chinese dynastic change: spatial and temporal variations of monsoonal rain". Chinese Science Bulletin 55 (32), 3734-3737. http://dx.doi.org/10.1007/s11434010-4122-3.

Christiansen, B., Charpentier Ljungqvist, F., 2012. The extra-tropical Northern Hemisphere temperature in the last two millennia: reconstructions of low frequency variability. Climates of the Past 8 (2), 765-786.

Chu, K.C., 1973. The preliminary research on climate change in China of past five thousand years. Science China (Ser A) 2, 15-38.

Chull, H.C., Choon, K.R., Kang, H.O., 2014. Late Holocene climate change and human impact inferred from the pollen record, Haman area, southern Korea. Quaternary International 344, 4-10. http://dx.doi.org/10.1016/j.quaint.2014.04.012.

CMA, 1981. Yearly Charts of Dryness/Wetness in China for the Last 500-Year Period. Sinomaps Press, Beijing.

Costanza, R., Graumlich, L., Steffen, W., et al., 2007. Sustainability or collapse: what can we learn from integrating the history of humans and the rest of nature? AMBIO 36, 522-527.

Crowley, T.J., Lowery, T.S., 2000. How warm was the medieval warm period? AMBIO: A Journal of the Human Environment 29, 51-54.

deMenocal, P.B., 2001. Cultural responses to climate change during the Late Holocene. Science 292 (5517), 667-673.

Dybdahl, A., 2012. Climate and demographic crises in Norway in medieval and early modern times. The Holocene 22, 1159-1167.

Fan, K.W., 2010. Climatic change and dynastic cycles in Chinese history: a review essay. Climate Change 101 (3-4), 565-573.

Fan, W.L., Mei, B.C., 1994. The General History of China. People's Publishing House, Beijing.

Fang, X.Q., Su, Y., Yin, J., et al., 2014. Methodology for quantifying social and economic series on the base of Semantic Differential to serve the research on impacts of climate change. Quaternary Science 34 (6), 1204-1214. 
Fang, X.Q., Su, Y., Yin, J., et al., 2015. Transmission of climate change impacts from temperature change to grain harvests, famines and peasant uprisings in the historical China. Science China: Earth Sciences 58, 1427-1439. http:// dx.doi.org/10.1007/s11430-015-5075-9.

Fang, X.Q., Xiao, L.B., Wei, Z.D., 2013. Social impacts of the climatic shift around the turn of the 19th century on the North China plain. Science China Earth Sciences $56,1044-1058$

Fu, L.C., 2010. The General History of China. Guizhou Education Press, Guiyang.

Fu, Z.F., 1981-1989. The Feudal Social and Economic History of China. People's Publishing House, Beijing.

Galloway, P.R., 1986. Long-term fluctuations in climate and population in the preindustrial era. Population and Development Review 12, 1-24.

Ge, Q.S., Hao, Z.X., Zheng, J.Y., et al., 2013b. Temperature changes over the past 2000 $\mathrm{yr}$ in China and comparison with the Northern Hemisphere. Climate of the Past 9, 1153-1160.

Ge, O.S., Liu, H.L., Zheng, J.Y., et al., 2013a. The climate change and social development over the last two millennia in China. Chinese Journal of Nature 35 (1), 9-21.

Ge, Q.S., Zheng, J.Y., Hao, Z.X., et al., 2010. Temperature variation through 2000 years in China: an uncertainty analysis of reconstruction and regional difference. Geophysical Research Letters 37, L03703. http://dx.doi.org/10.1029/2009G L041281.

Ge, Q.S., 2011. Climate Change through Ancient Chinese Dynasty. science press, Beijing.

Haug, G.H., Günther, D., Peterson, L.C., et al., 2003. Climate and the collapse of Maya civilization. Science 299 (5613), 1731-1735.

Hsiang, S.M., Burke, M., Miguel, E., 2013. Quantifying the influence of Climate on human conflict. Science 341 (6151). http://dx.doi.org/10.1126/science.1235367.

Huang, T.H., 1999. Outline of Chinese Financial History. Shanghai University of Finance and Economic Press, Shanghai.

IPCC, 2013. Climate Change 2013: the Physical Science Basis. Cambridge University Press, Cambridge.

Issar, A.S., Zohar, M., 2007. Climate Change: Environment and History of the Near East. Springer, Berlin/Heidelberg.

Jian, B.Z., Shao, X.Z., Hua, H., 2009. A Concise History of China. Peking University Press, Beijing.

Jiang, F.Y., 2004. Social and Economic History of the Wei, Jin and Southern and Northern Dynasties. Tianjin Ancient Books Publishing House, Tianjin.

Lamb, H.H., 1995. Climate, History and Modern World, second ed. Routledge, London.

Lee, H.F., Zhang, D.D., 2010. Changes in climate and secular population cycles in China, 1000 CE to 1911. Climate Research 42, 235-246.

Li, H.L., 1991. Chinese Peasants' Burden History. China Financial Economic Publishing House, Beijing.

Li, L.Q., 1988. Economic History of the Ming and Qing Dynasties. Guangdong Higher Education Press, Guangzhou.

Loehle, C., McCulloch, J.H., 2008. Correction to: a 2000-year global temperature reconstruction based on non-tree ring proxies. Energy Environment 19 (1) 93-100.

Lv, S.M., 2005. The General History of China. East China Normal University Press, Shanghai.

Mann, M.E., Zhang, Z.H., Rutherford, S., et al., 2009. Global signatures and dynamical origins of the little Ice Age and medieval climate anomaly. Science 326, 1256-1260.

Nunn, P., Hunter-Anderson, R., Carson, M., et al., 2007. Times of plenty, times of less: last-millennium societal disruption in the Pacific basin. Human Ecology 35, 385-401.

Osgood, C.E., 1957. The Measurement of Meaning. University of Illinois Press, Champaign, IL.

PAGES, 2009. Science Plan and Implementation Strategy (IGBP Report No. 57). IGBP Secretariat, Stockholm.

Pei, Q., Zhang, D.D., Lee, H.F., et al., 2014. Climate change and macro-economic cycles in pre-industrial Europe. PLoS One 9, e88155.

Peng, X.W., 2007. Chinese Monetary History. Shanghai People's Publishing House, Shanghai.

Shi, Z.W., Xiao, L.H., 1994. The General History of China, Economic, vol. 10. China Book Press, Beijing.

Solomon, S., 2007. Climate Change 2007-the Physical Science Basis: Working Group I Contribution to the Fourth Assessment Report of the IPCC, vol. 4. Cambridge University Press, Cambridge.

Su, Y., Fang, X.Q., Yin, J., 2014. Impact of climate change on fluctuations of grain harvests in China from the western Han Dynasty to the five dynasties (206 BC-960 AD). Science China: Earth Sciences 57 (1), 1-12.

Sun, W.X., Qi, H.P., 2008. Chinese Financial History. Dongbei University of Finance and Economics Press, Dalian.

Tan, L., Cai, Y., An, Z., et al., 2011. Climate patterns in north central China during the last $1800 \mathrm{yr}$ and their possible driving force. Climate of the Past 7, 685-692.

Tan, M., Liu, T., Hou, J., et al., 2003. Cyclic rapid warming on centennial-scale revealed by a 2650-year stalagmite record of warm season temperature. Geophysical Research Letters 30, 1617-1626.
Tol, R.S.J., Wagner, S., 2010. Climate change and violent conflict in Europe over the last millennium. Climatic Change 99, 65-79.

Twitchett, D.C., Fairbank, J.K., 1978-2009. The Cambridge History of China, vol. 15. Cambridge University Press, Cambridge.

Wang, J.Y., 2007. Modern Chinese Economic History (1895-1927). Economic Management Press, Beijing.

Wei, Z., Fang, X., Su, Y., 2014. Climate change and fiscal balance in China over the past two millenniums. The Holocene 24 (12), 1771-1784.

Wei, Z., Rosen, A.M., Fang, X., et al., 2015. Macro-economic cycles related to climate change in dynastic China. Quaternary Research 83 (01), 13-23.

Weiss, H., Bradley, R.S., 2001. What drives societal collapse? Science 291, 609-610.

Welc, F., Marks, L., 2014. Climate change at the end of the Old Kingdom in Egypt around 4200 BP: new geoarchaeological evidence. Quaternary International 324, 124-133.

Xiang, H.C., 2006. The General History of Chinese Finance Beijing. China Financial and Economic Publishing House.

Xiao, L.B., Fang, X.Q., Zheng, J.Y., et al., 2015. Famine, migration and war: comparison of climate change impacts and social responses in North China between the late Ming and late Qing dynasties. The Holocene 25 (6), 900-910. http://dx.doi.org/ $10.1177 / 0959683615572851$.

Yan, Z.P., 1989. Modern Chinese Economic History. People's Publishing House, Beijing.

Yancheva, G., Nowaczyk, N.R., Mingram, J., et al., 2007a. Influence of the intertropical convergence zone on the East-Asian monsoon. Nature 445 (7123), 74-77. http://dx.doi.org/10.1038/nature 05431.

Yancheva, G., Nowaczyk, N.R., Mingram, J., et al., 2007b. Yancheva et al. reply. Nature 450 (7168), E8-E9.

Yang, B., Braeuning, A., Johnson, K.R., et al., 2002. General characteristics of temperature variation in China during the last two millennia. Geophysical Research Letters 29, 38-1-38-4.

Yin, J., Su, Y., Fang, X.Q., 2015. Relationships between temperature change and grain harvest fluctuations in China from 210 BC to 1910 AD. Quaternary International 355, 153-163.

Zhang, C.X., 1991. The General History of Ancient China. Peking University Press, Beijing.

Zhang, D.E., Li, H.C., Ku, T.L., et al., 2010a. On linking climate to Chinese dynastic change: spatial and temporal variations of monsoonal rain. Chinese Science Bulletin 55 (1), 60-67. http://dx.doi.org/10.1007/s11434-009-0584-6.

Zhang, D.E., Li, H.C., Ku, T.L., et al., 2010b. Reply to the comment of Cheng, et al. Chinese Science Bulletin 55 (32), 3738-3740. http://dx.doi.org/10.1007/s11434010-4137-9.

Zhang, D.E., Lu, L.H., 2007. Anti-correlation of summer and winter monsoons? Nature 450 (7168), E7-E8. http://dx.doi.org/10.1038/nature06338.

Zhang, D.E., 2008. Query the validity of the monsoon led to the collapse of the Tang dynasty by the chinese historical climate records. Advances in Climate Change Research 4 (2), 126-130.

Zhang, D.D., BRECKE, P., LEE, H.F. et al., 2007. Global climate change, war, and population decline in recent human history. Proceedings of the National Academy of Sciences of the United States of America 104 (49), 19214-19219.

Zhang, D.D., Lee, H.F., Wang, C., et al., 2011. The causality analysis of climate change and large-scale human crisis. Proceedings of the National Academy of Sciences of the United States of America 108, 17296-17301.

Zhang, D.D., Pei, Q., Lee, H.F., et al., 2015. The pulse of imperial China: a quantitative analysis of long-term geopolitical and climatic cycles. Global Ecology and Biogeography 24 (1), 87-96.

Zhang, J.C., 1988. The Reconstruction of Climate in China for Historical Times. Science Press, Beijing.

Zhang, P.Y., 1996a. Climate Change in Chinese History. Shandong Science and Technology Press, Jinan.

Zhang, P.Y., 1996b. Climate Changes in China During Historical Times. Shandong Science and Technology Press, Ji'nan, pp. 198-274.

Zhang, P.Z., Cheng, H., Edwards, R.L., et al., 2008. A test of climate, Sun, and culture relationships from an 1810-year chinese cave record. Science 322 (5903), 940-942.

Zhang, Q.Z., 2001. Chinese History, vol. 4. Higher Education Press, Beijing.

Zhao, D.X., 2002. The General History of Chinese Economy. Hunan People's Publishing House, Changsha.

Zheng, J.Y., Wang, W.C., Ge, Q.S., et al., 2006. Precipitation variability and extreme events in eastern China during the past 1500 years. Terrestrial, Atmospheric and Oceanic Sciences 17, 579-592.

Zheng, J.Y., Xiao, L.B., Fang, X.Q., 2014. How climate change impacted the collapse of the Ming dynasty. Climatic Change 127 (2), 169-182.

Zhou, B.D., 1981. Chinese Financial History. Shanghai People's Publishing House, Shanghai.

Zhou, Z.Q., 2007. The General History of Chinese Economy. Economic Daily Press, Beijing.

Zhu, B.K., Zheng, K.S., 1995. The General History of Chinese Economy. China Social Sciences Press, Beijing. 